\title{
Usefulness of the Evolution mechanical dilator sheath for endocardial lead extraction - preliminary results
}

Zastosowanie mechanicznego systemu Evolution do usunięcia elektrod endokawitarnych wyniki wstępne

\section{Andrzej Przybylski, Paweł Syska, Artur Oręziak, Aleksander Maciąg, Maciej Sterliński, Krzysztof Kuśmierski, Mariusz Kuśmierczyk}

Institute of Cardiology, Warsaw, Poland

Post Kardiol Interw 2010; 6, 2 (20): 59-65

DOI: $10.5114 /$ pwki.2010.14164

\begin{abstract}
Background: Due to the growing use of pacemakers, implantable cardioverter-defibrillators (ICD) and cardiac resynchronization therapy units as well as the prolongation of life of the devices' recipients, an increasing number of patients require lead extraction. There are several methods of transvenous extraction.

Aim: To report the first Polish experience with the new, mechanical system for lead extraction (Evolution).

Methods: Between January 2008 and April 201045 patients underwent extraction of 76 leads. Median implantation time was 3.3 years (range $0.1-26$ years). There were 68 pacing leads and 11 ICD leads. Thirty one (41\%) leads were removed with manual traction, in other cases the Byrd dilatators or femoral approach were used. The Evolution system was used only if the other methods were not successful.

Results: Seventy two (95\%) leads were completely and two partially extracted. Two leads (2.5\%) could not be removed. The Evolution system was used in 3 patients (6 leads, $8 \%$ ). All but one lead were successfully extracted with the Evolution sheaths. There were no major complications. One patient required blood transfusion due to intraoperative bleeding (minor complication).

Conclusion: The Evolution system seems to be a safe method to improve success rates of lead extraction.
\end{abstract}

Key words: lead extraction, cardiac pacemakers, implantable cardioverter-defibrillators

\section{Streszczenie}

Wstęp: Wraz ze zwiększeniem liczby implantacji stymulatorów, kardiowerterów-defibrylatorów i układów resynchronizujących oraz wydłużeniem czasu życia pacjentów w tej grupie, rośnie liczba chorych wymagających usunięcia wcześniej wszczepionych elektrod.

Cel: Przedstawienie własnych, pierwszych w Polsce doświadczeń z usuwania elektrod za pomocą systemu Evolution.

Metody: W okresie pomiędzy styczniem 2008 r. a kwietniem 2010 r. zabieg usunięcia elektrod wykonano u 45 chorych (76 elektrod). Średni okres od implantacji elektrody wynosił 3,3 roku (0,1-26 lat). Wśród usuwanych elektrod 68 było elektrodami stymulującymi, a 11 defibrylującymi.

Wyniki: Trzydzieści jeden (41\%) elektrod zostało usuniętych trakcją manualną. W pozostałych przypadkach stosowano koszulki Byrda lub technikę wykorzystującą dostęp przez żyłę udową. System Evolution był stosowany w przypadkach niepowodzenia innych technik. Całkowicie usunięto 72 (95\%) elektrody, a 2 częściowo. Dwóch elektrod nie udało się usunąć. System Evolution zostat zastosowany u 3 chorych do ekstrakcji 6 elektrod (8\%), z których usunięto w całości 5. W jednym przypadku elektrodę pozostawiono. Nie wystąpiły poważne powikłania zabiegu. Jeden chory wymagał transfuzji krwi ze względu na krwawienie śródzabiegowe.

Wniosek: System mechaniczny Evolution jest bezpieczną metodą ekstrakcji elektrod, zwiększającą skuteczność zabiegu.

Słowa kluczowe: usuwanie elektrod endokawitarnych, stymulatory serca, kardiowertery-defibrylatory

Adres do korespondencji/Corresponding author:

dr n. med. Andrzej Przybylski, Instytut Kardiologii, ul. Alpejska 42, $02-638$ Warszawa, tel.: + 4822343 44 17, fax: +48 2234345 20,

e-mail: aprzybylski@ikard.pl

Praca wpłynęła 13.05.2010, przyjęta do druku 4.06.2010. 


\section{Introduction}

There has been a growing number of patients requiring endocardial lead extraction in recent years. This is related to:

- increased number of implanted pacemakers, cardiovererdefibrillators (ICD) and resynchronization systems (cardiac resynchronization therapy, CRT) [1],

- increased life expectancy in patients with implanted devices, which causes an increased number of device replacement or upgrading procedures (to ICD or CRT),

- igrowing number of cases of damaged leads (especially defibrillating leads).

Despite development of new techniques of lead extraction the procedure is still related to high risk of serious complications or procedure failure [2-5]. This is mainly caused by the presence of adhesions between the lead and the cardiovascular system. Different methods including mechanical force, radiofrequency energy or laser techniques have been used to separate leads from the surrounding connective tissue [2, 6-8]. Mechanical methods are still the most commonly used. This is caused by a longlasting experience in their application, high availability of the devices and economic aspects. Moreover, some studies reported similar results for these devices in comparison to newer techniques [9-11].

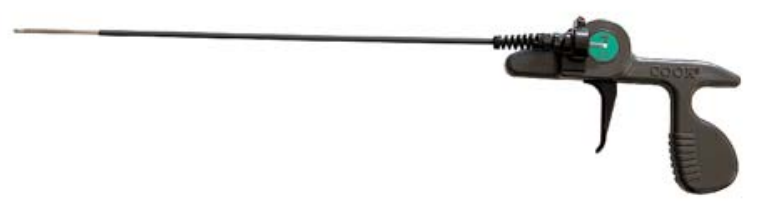

Fig. 1. Evolution mechanical dilator sheath (Cook Medical Inc.) - device design. The trigger causes a rotation of a threaded barrel distal tip in order to dissect the adhesions between lead and the vessel Ryc. 1. System Evolution firmy COOK - widok urządzenia. Zwraca uwage uchwyt w ksztatcie spustu powodujacy rotację wewnętrznej koszulki zakończonej metalowym pierścieniem mającym za zadanie uwolnienie elektrody ze zrostów

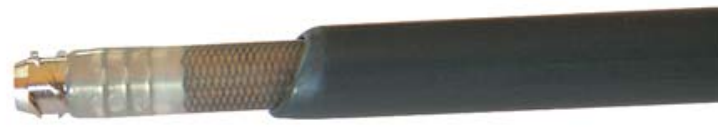

Fig. 2. Evolution mechanical dilator sheath (Cook Medical Inc.) - enlargement of the metal tip of the inner sheath

Ryc. 2. System Evolution firmy COOK - zbliżenie metalowego zakończenia koszulki wewnętrznej
One of the newest mechanical methods is the use of Evolution sets (Cook Medical Inc. Bloomington, USA). Their inventiveness comes from the fact that the inner sheath is ended with a metal ring, which can be given a rotational force by the use of a handle resembling a gun trigger (fig. 1). Rotational movement of the sheath ended with a metal ring (fig. 2) is used to liberate the lead from the fibrous tissue. There have been no Polish reports on the use of the Evolution system. Besides, only single reports on its application can be found in the literature [12].

The aim of the study was to present our own, first in Poland experiences with the lead extraction Evolution system.

\section{Materials and methods}

\section{Studied group}

The analysis included a group of consecutive 45 patients who underwent a percutaneous extraction of an endocardial lead between January 2008 and April 2010 (during that period the Evolution system was available at our site).

Table 1. Baseline clinical characteristics

Tabela 1. Charakterystyka kliniczna badanej grupy

\begin{tabular}{lc} 
Age [years] (SD) & $58.1(19.5)$ \\
\hline Men (\%) & $32(71.1)$ \\
\hline NYHA class (\%) & \\
I/II & $34(75.6)$ \\
III/IV & $11(24.4)$ \\
\hline Primary disease & \\
coronary artery disease & 13 \\
hypertrophic cardiomyopathy & 8 \\
dilated cardiomyopathy & 4 \\
other & 20 \\
\hline Previous cardiac surgeries & 8 (including 4 heart \\
& transplantations)
\end{tabular}

\begin{tabular}{l}
\hline Type of the implanted device \\
single chamber ventricular pacemaker (VVI) \\
dual chamber pacemaker (DDD) \\
ICD-VR (single chamber) \\
ICD-DR (dual chamber) \\
CRT-P \\
CRT-D \\
Median time from lead implantation \\
[years] (min. - max.) \\
Number of previous procedures on the device \\
(replacements, upgrades) \\
0 \\
1 \\
2 \\
$2.3(0.1-26)$ \\
\end{tabular}

ICD - implantable cardioverter-defibrillator, CRT-P - cardiac resynchronization therapy, CRT-D - cardiac resynchronization therapy with cardioverter-defibrillator

ICD - kardiowerter-defibrylator, CRT-P - stymulator resynchronizuja$c y, C R T-D$ - kardiowerter-defibrylator z opcja terapii resynchronizującej 
Qualification for the procedure was based on the current guidelines established by cardiologic societies [2]. Patients baseline characteristics are presented in table 1. Indications for the procedure included mainly infective complications related to implanted devices, but also lead damage and in some cases the need of system upgrade - table 2.

\section{Procedure description}

Procedures were set in the cardiosurgical operating room with possibility of emergency sternotomy and surgery with the use of extracorporeal circulation. All patients signed an informed consent for the procedure and for general anaesthesia. Intratracheal general anaesthesia was used. ECG, blood and central venous pressure and pulsoxymetry were monitored continuosuly throughout the procedure. All steps of the procedure related to manouvers inside the cardiovascular system were performed under direct fluoroscopy. Patients in need of permanent pacing had a temporary lead introduced through the femoral or cubital fossa vein contralateral to the side of the previously implanted device.

After opening of the pacemaker/ICD pocket and removal of the pulse generator, leads were mobilised from ligatures with the use of an electric knife. In case of removal of more the one lead, left ventricular lead was extracted first (from the cardiac veins system), followed by removal of an atrial and a right ventricular lead. After liberation of a lead from ligatures and connective tissue adhesions inside the pocket, a standard leader was introduced through the lumen of a lead to assess the patency of the central canal necessery for the placement of the locking-stylet leader (for example Liberator, Cook). To disconnect the actively fixed lead from the endocardium the fixation element was unscrewed under direct fluoroscopy. These manouvers were followed by an attampt to extract the lead with the use of manual traction. If manual traction had failed leads were removed percutaneously with the use of a set of metal, polypropylene and teflon Byrd dilators (Cook). After adequate preparation of the lead (cutting of the IS-1 tip, dilation of the central canal ostium, placement of the locking-stylet leader and long ligatures at the isolation of the distal tip of a lead which were than used to give tension on the lead during introduction of a dilator) an attempt was made to disconnect the lead from the connective tissue adhesions throughout its way in the venous system with the use of adequate dilators. Steinless steel sheaths were used to reduce the resistance between the clavicula and the first rib. Its use seemed especially needed in case of calcifications of the costoclavicular ligament. After elimination of resistance related to strangulation of a lead in the proximity of the costoclavicular ligament, the steinless steel sheaths were retracted and the new set of telescope sheaths adjusted to the size of the lead (7-16 F) was introduced. During
Table 2. Indications for lead extraction

Tabela 2. Wskazania do zabiegów przezskórnego usunięcia elektrod

\begin{tabular}{lc} 
Indication & Number of patients, \\
& $\mathrm{n}(\%)$ \\
\hline Device infection & $19(42)$ \\
local infection without fistula & 1 \\
local infection with fistula & 15 \\
systemic infection/IE & 3 \\
\hline Lead damage & $12(27)$ \\
\hline System upgrade & $7(16)$ \\
\hline Remaining leads (after heart transplantation) & $4(9)$ \\
\hline Perforation of the heart & $3(6)$ \\
\hline IE - infective endocarditis &
\end{tabular}

introduction of successive sheaths lead was mildly pulled with the use of locking-stylet leader and ligatures placed around its corpus. A decision to use Evolution system (Cook) was taken in case of unsuccessful separation of the lead from adhesions with the use of teflon or polypropylene sheaths, especially on its passage through the subclavian and innominate vein.

If a free tip of an lead was situated inside the vascular system preventing its capture via an upper access, a lower access via a femoral vein was used by introduction of a teflon sheath ended with a special loop enabling capture of the lead tip and its introduction inside the sheath (Needles-Eye, Cook). After capturing of the lead and its placement inside the sheath its was possible to perform a counter-traction to liberate the lead tip from the endocardium.

Success of the procedure and procedure complications were defined according to current recommendations of the cardiologic societies.

\section{Statistical analysis}

Continuous variables are presented as arithmetic means \pm standard deviations (SD) and categorical variables as numbers and percentages (\%).

\section{Results}

In the studied group of 45 patients extraction of 76 leads was attempted. Data on the type and number of removed leads are presented in table 3 .

Extracted leads consisted mainly of pacemaker leads, but in 8 cases defibrillating lead were removed. The proportion of actively or passively fixed leads was similar with insignificant excess of actively fixed leads.

Two leads were extracted at the same time in half of the patients. Three patients underwent extraction of 3 leads. Fully successful procedure defined as a complete lead extraction was obtained in $95 \%$ of cases. 
Table 3. Lead number and type

Tabela 3. Rodzaje oraz liczba usuwanych elektrod

\begin{tabular}{lc} 
Type & Number of leads, $\mathbf{n}(\%)$ \\
\hline All & 76 \\
\hline $\begin{array}{l}\text { Localization of a lead } \\
\text { righ atrium }\end{array}$ & $28(37)$ \\
$\quad$ right ventricle & $44(58)$ \\
coronary sinus & $4(5)$ \\
\hline Type of a lead & $68(89)$ \\
pacing & $8(11)$ \\
defibrillating & \\
\hline Mode of fixation & $34(45)$ \\
passive & $42(55)$ \\
active & Number of patients \\
\hline Number of leads extracted at one time & 17 \\
\hline 1 & 25 \\
2 & 3
\end{tabular}

Table 4. Technical details of the procedures

Tabela 4. Szczegóty techniczne zabiegów

\begin{tabular}{lc} 
General strategy & Number of leads, $\mathrm{n}(\%)$ \\
direct traction & $31(41)$ \\
use of the Cook system & $45(59)$ \\
\hline Variants of the Cook systems used* & $\mathrm{N}$ \\
telescope Byrd dilators & 44 \\
locking stylet (Liberator) & 36 \\
Evolution system & $(3$ patients) \\
femoral vein access & 6 \\
\hline Procedure result & $\mathrm{n}(\%)$ \\
complete lead extraction & $72(95)$ \\
partial lead extraction & $2(2.5)$ \\
abandonement of the whole lead & $2(2.5)$ \\
\hline Serious complications & 0
\end{tabular}

\section{Techniques used}

Direct traction allowed extraction of 31 (41\%) leads. In the remaining cases the counter-traction method with application of the Cook system elements was used (tab. 4). The oldest leads extracted with the use of a direct traction had been implanted 5 years before. These were pacing leads and one of them was a passive fixation lead.

\section{The use of the Evolution system}

The Evolution system was used for extraction of 6 leads ( $8 \%-2$ defibrillating leads and 4 pacing leads) in 3 patients. This technique was applied only after separation of leads from adhesions had been impossible with the use of Byrd sheaths. Five leads were completely extracted. One defibrillating lead was not completely removed, because

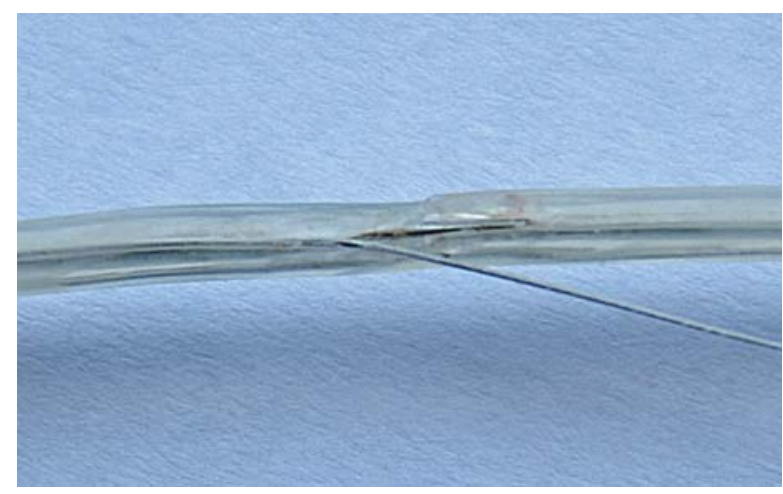

Fig. 3. Defibrillation lead failure - an insulation and inner leads defect is clearly visible

Ryc. 3. Uszkodzona elektroda defibrylujaca z widocznym przerwaniem ciągłości izolacji oraz przewodów wewnętrznych

its adherence to the innominate vein could not have been overcome. This situation occurred in a 22-year-old female patient after an ICD implantation 4 years before in the secondary profilaxis of sudden cardiac death.

\section{Complications}

Complications were classified according to definitions proposed by cardiologic societies [2]. There were no serious complications observed in the analyzed group (death, the need for surgical intervention, pulmonary embolism, complications related to anaesthesia, stroke, infection of the device implanted on the contralateral side).

One patient required blood transfusion due to procedural blood loss. This patient was subjected to extraction of two pacing leads implanted 3 years before with subsequent implantation of CRT-D. Telescope sheaths and Evolution system were used for lead removal in this case.

\section{Discussion}

We present for the first time in Poland the application of a new method of endocavitary lead extraction based on the Evolution system. This system was used for extraction of 6 out of 76 leads (8\%) in the analyzed group. In all cases the technique was applied after extraction with means of other methods had failed. Five leads were completely extracted and there was one extraction failure. There was no serious complications related to the use of the Evolution technique.

This method was a subject of only few reports found in the current literature [12]. It may be partially related to a short time which has passed since the introduction of this system. The largest group of procedures performed with the use of the Evolution system was presented by 


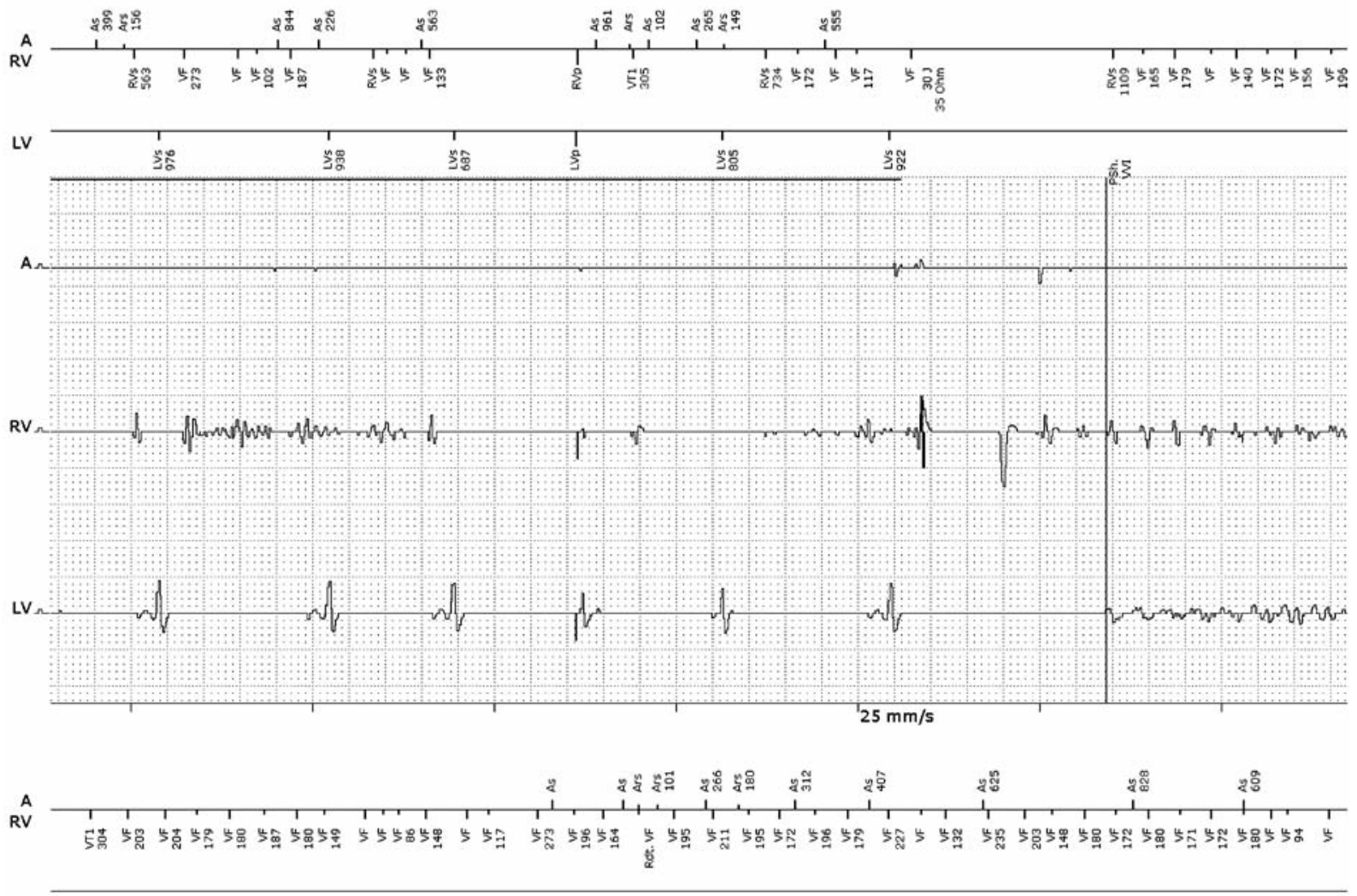

Lv

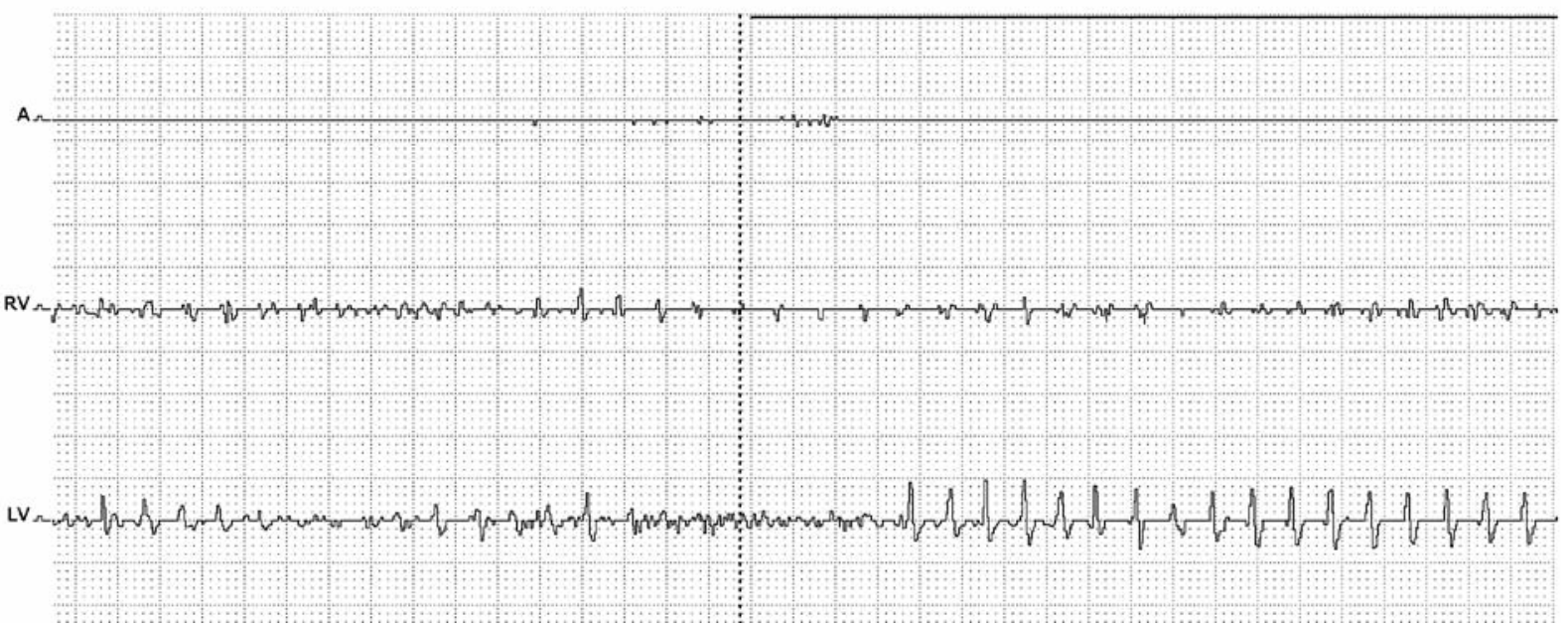

Fig. 4. The consequences of the lead failure presented on the previous figure. The data stored in the device memory (Lumax 300 HF-T, Biotronik). The spurious shock is caused by the noise in the right ventricular channel (RV) detected as ventricular fibrillation (VF). Note the normal intracardiac electrogram in the left ventricular channel (LV). The inappropriate shock induce true ventricular fibrillation (detected both in the right and in the left ventricular channel). The atrial channel (A) is blinded due to chronic atrial fibrillation

Ryc. 4. Konsekwencje uszkodzenia elektrody przedstawionego na poprzedniej rycinie. Zapis interwencji z pamięci CRT-D (Lumax 300 HF-T, Biotronik). Nieadekwatne wyładowanie na skutek błędnego rozpoznania migotania komór (VF) spowodowanego uszkodzeniem elektrody defibrylujacej. Szum w kanale prawokomorowym (RV) decydujacym o detekcji arytmii, prawidłowy zapis w kanale lewokomorowym (LV). Nieuzasadniona defibrylacja wywołuje migotanie komór (widoczna detekcja zarówno w kanale RV, jak i LV). Kanat przedsionkowy (A) jest zaślepiony (przetrwate migotanie przedsionków) 
Hussein et al. [12]. This technique was used in 29 patients, in whom extraction of 41 leads was attempted in years 2008-2009. The Evolution system was used as a method of choice for lead extraction in 12 patients (16 leads). In this group of patients $100 \%$ success rate was obtained. In the remaining cases (17 patients, 25 leads) the Evolution system was used after other techniques had prooven unsuccesfull. In this group of patients the rate of successful extractions was lower (77\%). Application of additional techniques was necessary in 4 patients (the use of a loop introduced via a femoral vein in 2, laser sheaths in 2).

Our results are similar to the findings presented in the cited report. We used the Evolution system solely in cases of unsuccessful lead extraction with means of other techniques (direct traction, Byrd sheaths), which happens frequently when the structure of a lead is damaged making the procedure more difficult. Rare use of the Evolution system is mainly related to a relatively high price of the system. It should be mentioned that lead extraction procedures performed for indications other than infective endocarditis are not reimbursed by the National Health Fund.

Of note, infective complications (infection of the pocket, infective endocarditis) were an indication for the procedure in only $42 \%$ of patients. In the remaining cases indication for the extraction consisted of lead damage or the need for removal of unnecessary leads prior to system upgrade (for example an upgrade of pacing device to (RT-D). Is seems likely that these indications will predominate in the near future $[6,9,13]$. It is related to the extension of indications for multi-lead device implantation (such as CRT-D) and frequent lead damage (especially defibrillating leads). Another problem is venous obstruction at the side of implantation which prevents further lead implantations. Venous obstruction is caused mainly by the adhesions between the lead and the vascular wall. Their presence is a cause of the most severe difficulties related to lead extraction [10, 14]. Adhesions are often found in the subclavian or/and innominate vein, particularly in young people. Liberation of a lead is also difficult when proximal defibrillating coil is situated in the subclavian vein. The fact that it was impossible to remove the proximal part of the lead in 4 patients during heart transplantation in our group best exemplifies how strongly can the lead adhere to the vascular wall. These patients required extraction of remaining lead fragments with the use of described methods. In two of them extracted lead was a defibrillating dual-coil type and in the third case a pacing lead.

On the other hand, in some patients it was possible to extract leads with means of direct traction even long time after implantation ( $41 \%$ of leads). These situations included leads implanted 5 years before. Similar results were presented by other authors. Using this technique Kutarski et al. extracted 33 leads implanted at least one year before [9]. Therefore it seems resonable to attempt a direct traction method in each case of lead extraction $[7,15]$. It should be remembered that direct traction must be gentle in order not to damage the lead structure, which makes the subsequent removal difficult.

\section{Study limitations}

It was impossible to compare the use of the Evolution system with other, newer techniques of lead extraction (laser, radiofrequency current), because they were not available.

In our study the Evolution system was applied only after failed extraction by means of other methods and therefore we were unable to compared times of procedure or fluosroscopy.

\section{Conclusion}

The mechanical Evolution system is a safe method of lead extraction and increases the effectiveness of the procedure.

\section{References}

1. The EHRA White Book. The Current Status of Cardiac Electrophysiology in ESC Members Countries. http://www.escardio.org/communities /EHRA.

2. Wilkoff BL, Love CJ, Byrd CL, et al. Heart Rhythm Society; American Heart Association. Transvenous lead extraction: Heart Rhythm Society expert consensus on facilities, training, indications, and patient management: this document was endorsed by the American Heart Association (AHA). Heart Rhythm 2009; 6: 10851104.

3. Smith MC, Love CJ. Extraction of transvenous pacing and ICD leads. Pacing Clin Electrophysiol 2008; 31: 736-752.

4. Wilkoff BL, Byrd CL, Love CJ, et al. Pacemaker lead extraction with the laser sheath: results of the pacing lead extraction with the excimer sheath (PLEXES) trial. J Am Coll Cardiol 1999; 33: 16711676.

5. Kennergren C, Bucknall CA, Butter C, et al. PLESSE investigators group. Laser-assisted lead extraction: the European experience. Europace 2007; 9: 651-656.

6. Kennergren CA. European perspective on lead extraction: part I. Heart Rhythm 2008; 5: 160-162.

7. Kennergren CA. European perspective on lead extraction: part II. Heart Rhythm 2008; 5: 320-323.

8. Neuzil P, Taborsky M, Rezek Z, et al. Pacemaker and ICD lead extraction with electrosurgical dissection sheaths and standard transvenous extraction systems: results of a randomized trial. Europace 2007; 9: 98-104.

9. Kutarski A, Małecka B, Ruciński P, et al. Percutaneous extraction of endocardial leads - a single centre experience in 120 patients. Kardiol Pol 2009; 67: 149-156.

10. Bongiorni MG, Soldati E, Zucchelli G, et al. Transvenous removal of pacing and implantable cardiac defibrillating leads using single sheath mechanical dilatation and multiple venous approaches: high success rate and safety in more than 2000 leads. Eur Heart J 2008; 29: 2886-2893. 
11. Hussein AA, Wilkoff BL, Martin DO, et al. Initial experience with the Evolution mechanical dilator sheath for leadextraction: safety and efficacy. Heart Rhythm 2010 Mar 23.

12. Calvagna GM, Evola R, Scardace G, et al. Single-operator experience with a mechanical approach for removal of pacing and implantable defibrillator leads. Europace 2009; 11: 1505-1509.

13. Jones SO 4th, Eckart RE, Albert CM, et al. Large, single-center, single-operator experience with transvenous lead extraction: outcomes and changing indications. Heart Rhythm 2008; 5 : 520-525.
14. Novak M, Dvorak P, Kamaryt P, et al. Autopsy and clinical context in deceased patients with implanted pacemakers and defibrillators: intracardiac findings near their leads and electrodes. Europace 2009; 11: 1510-1516.

15. Kennergren C, Bjurman C, Wiklund R, Gäbel J. A single-centre experience of over one thousand lead extractions. Europace 2009; 11: 612-617. 